\title{
Death of Two FPS Vice-Presidents
}

The death of Lord Hurcomb GCB KBE in August and of Captain Charles Pitman CBE DSO MC in September last year deprived the FPS of two valued counsellors and longstanding friends. Lord Hurcomb had been a Vice-President since 1960, having joined the Society in 1952 and been made a member of Council in 1956. Until within a few months of his death at the age of 92 he regularly attended Council meetings, where his incisive mind, clear judgment and vast experience made a great contribution. Few men have been so intimately concerned with so many important British conservation bodies and have contributed so much to the cause.

\section{Lord Hurcomb}

In an appreciation Sir Landsborough Thomson writes: With the death of Cyril Hurcomb, in his 93rd year, many of us have lost a kindly friend, conservation bodies a wise counsellor, and the cause of nature preservation a doughty champion. The gifts which brought him high distinction in the public service, with the great experience of men and affairs gained therein, made him a most valuable colleague. He was a keen and knowledgeable field naturalist, with a particular interest in British birds.

An outstanding contribution was steering through the House of Lords the measure that became the Protection of Birds Act 1967. This removed some blemishes in the Act of 1954, itself a great advance on earlier legislation. He was Founder-President of the Council for Nature, 1958-64; and in this and other chairs his shrewdness and tact - with the patent sincerity of his own views - smoothed over many potential difficulties. As well as Vice-President of the FPS, he was at different times President of the Royal Society for the Protection of Birds and of the Society for the Promotion of Nature Reserves. For several years he was Chairman of the British Section of the International Council for Bird Preservation. He had been a member of the Nature Conservancy, Chairman of its Committee for England, and for one year Chairman of the Conservancy itself. He was also a Trustee of the British National Appeal of the World Wildlife Fund and continued to be a member of its Allocations Committee for some years after his resignation as a Trustee.

\section{Charles Pitman}

Captain Pitman was a member of the Society for 50 years. He was elected to Council in January 1952 and made a Vice-President in 1958; to the very last he was an active and regular attender at our meetings. $A$ frequent contributor to Oryx, he was even reviewing books in his hospital bed during his last illness. This appreciation of him and his work is by his friend and fellow Council member, Dr E. Barton Worthington:

Charles Pitman's death is a major loss to the conservation movement. He started by soldiering in India, and during the first world war in Mesopotamia collected military honours, but his most memorable work began in 1925 when 
he was appointed the first game warden for conservation in East Africa in association with his opposite numbers, Archie Ritchie in Kenya and Monty Moore in Tanganyika.

I first enjoyed the hospitality of Charles and his wife, Marjorie, who survives him, in 1927, so for nearly half a century have been privileged to count them as close friends. At the time I was engaged on the first fishery surveys of Lakes Victoria, Albert and others, and I recall the then Governor of Uganda, Sir William Gowers, another stalwart supporter of the FPS, introducing me: 'Now Charles, I know you are already an authority on our snakes, mammals and birds, but now you have got to have a go at the fish too'. Pitman added responsibility for fisheries to his department and laid down principles for their development which have served Uganda well. After the second world war, during which he was soldiering again as OC of the Uganda Defence Force, came proposals for National Parks, and Pitman was of course in the forefront. His recommendations for areas and his organisation of the first two parks provided a cornerstone for Uganda's first development plan (1946-56), and were pressed forward by the then Governor, Sir John Hall. The idea took a few years to be converted into legislation, however, so it was not until Sir Andrew Cohen's governorship that the Uganda parks achieved their worldwide reputation for tourism and wise management.

Although Charles Pitman lived for 85 years he was extremely active to the end and had recently added the conservation of rare breeds of domestic animals to his many interests. He was devoted to children and people as well as to animals of all kinds. Personal recollections will, I suppose, fade with the years; but fortunately much remains on the permanent record through his writings. A Game Warden among his Charges and A Game Warden takes Stock were among the first - and are still some of the best - among the spate of wildlife books; his guide to the Snakes of Uganda and numerous writings on ornithology have added much to zoological science, which was always his abiding interest.

\section{Two Reports}

It is good to see the independent Nature Conservancy Council once more with a report of its own (HMSO, £2.25), covering the period November 1st, 1973 to March 31st, 1975, after its prolonged suppression and strangulation by the uncomprehending NERC. Once more we have the information about our national nature reserves and other important national conservation issues that NERC so wilfully deprived us of for five long years. It is too soon to say how successful the NCC is really going to be, but it seems to have made a good start.

In its thirteenth annual report the World Wildlife Fund, 1110 Morges, Switzerland reveals its best year yet, with $\$ 4,138,416$ allocated in grants to 370 projects in some 45 countries, not to mention an increase of half a million dollars to $\$ 5.6 \mathrm{~m}$ in its capital and reserve funds invested in Switzerland. Even while we realise that these sums are a drop in the bucket compared with what is really needed to conserve wildlife worldwide, we can be pleased and proud at the achievement in so relatively short a time.

R.F.

For details of FPS meetings, including the Annual General Meeting on June 16th, see page 320 . 